\title{
Budidaya Jamur Tiram dan Olahannya untuk Kemandirian Masyarakat Desa
}

\author{
Zulfarina $^{1 *}$, Evi Suryawati ${ }^{1}$, Yustina ${ }^{1}$, Riki Apriyandi Putra ${ }^{1}$, dan Hendra Taufik ${ }^{2}$ \\ ${ }^{1}$ FKIP, Universitas Riau, Kampus Bina Widya Km 12.5, Simpang Baru, Tampan, Pekanbaru, Riau 28293 \\ ${ }^{2}$ Fakultas Teknik, Universitas Riau, Kampus Bina Widya Km 12.5, Simpang Baru, Tampan, Pekanbaru, \\ Riau 28293 \\ *zulfarina@lecturer.unri.ac.id
}

Submisi: 08 Januari 2019; Penerimaan: 29 November 2019

\begin{abstract}
Kata Kunci:
baglog;

budidaya;

olahan jamur

tiram;

jamur tiram

Abstrak Perguruan Tinggi Universitas Riau dengan program Desa Binaan melakukan kegiatan transfer teknologi tentang budidaya jamur tiram dalam kegiatan pengabdian. Tujuan dari pengabdian ini adalah untuk memberdayakan masyarakat dengan budidaya jamur tiram dan cara pengolahan jamur tiram sehingga dapat meningkatkan kesejahteraan masyarakat desa Seko Lubuk Tigo Kecamatan Lirik Kabupaten Indragiri Hulu Provinsi Riau. Metodenya adalah: Pemberian Materi tentang budidaya jamur tiram dan olahannya; Diskusi tentang berbagai masalah dan solusinya; Manajemen Usaha dan Pemasaran Produk; Simulasi dan evaluasi. Kegiatan Pengabdian ini dilakukan pada bulan Juni sampai Oktober 2019 Pelaksanaan kegiatan dengan melibatkan mahasiswa Kuliah Kerja Nyata Universitas Riau sebagai fasilitator. Hasil evaluasi dari kegiatan ini menunjukkan bahwa budidaya jamur tiram dan olahannya memberikan dampak positif bagi masyarakat setempat. Masyarakat sangat respon terhadap kegiatan ini. Prospek pasar jamur tiram masih mempunyai peluang yang cukup besar. Luaran dari kegiatan ini adalah masyarakat telah mampu melakukan budidaya jamur tiram dan pengolahannya. Selain itu juga dihasilkan buku referensi tentang budidaya jamur tiram.
\end{abstract}

Keywords: baglog; cultivation; oyster mushroom; oyster mushroom's products
Abstract University of Riau with the fostered village program was conducted technology transfer activities on the cultivation of oyster mushrooms in the engagement. The purpose of engagement was to empower the community by cultivating oyster mushrooms and processing oyster mushrooms into products so that they could improve the welfare of Seko Lubuk Tigo village, Lirik District, Indragiri Hulu Regency, Riau Province. The methods used in this activity were: Workshop about The Cultivation of Oyster Mushrooms and Its Processed Products; Discussion of Various Problems and Solutions; Business Management and Product Marketing; Simulation and Evaluation. This Community Service is conducted from June to October 2019. The activity was carried out by involving community service program students of University of Riau as facilitators. The evaluation results of this activity indicated that the cultivation of oyster mushrooms and their preparations had a positive impact on the local community. The community was very responsive to this activity. The prospect of the oyster mushroom market still has considerable opportunities. The output of this activity was the community has been able to do oyster mushroom cultivation and processing. It also produced a reference book about the cultivation of oyster mushrooms. 


\section{PENDAHULUAN}

Desa Seko Lubuk Tigo secara administratif berada di Kecamatan Lirik, Kabupaten Indragiri Hulu, Provinsi Riau. Desa ini terletak di daerah dataran tinggi dan berbukitbukit. Dalam pembagian wilayahnya, Desa Seko Lubuk Tigo terdiri dari 4 (empat) dusun, dengan 4 RW, 12 RT. Luas wilayah \pm 48000 Ha yang mana sekitar 2,32\% adalah lahan tanah kering, 24,01\% adalah lahan tanah basah, dan sekitar 73,67\% adalah lahan tanah perkebunan. Mata pencaharian masyarakat Desa Seko Lubuk Tigo adalah bertani (75,09\%). Sisanya sebagai, Pegawai Negeri Sipil (PNS), Swasta dan buruh (Monografi Desa Seluti 2018). Infrastruktur Desa masih kurang memadai, jalan-jalan masih belum diaspal. Sarana pendidikan sekolah yang tersedia hanya satu sekolah dasar.

Jamur tiram merupakan salah satu komuditas yang sedang diminati masyarakat untuk memenuhi kebutuhan pangan. Hal ini dapat dilihat dari permintaan yang terus meningkat setiap tahunnya. Permintaan jamur tiram yang cukup tinggi masih belum terpenuhi, masih banyak yang di datangkan dari luar daerah. Berdasarkan hal tersebut perlu dilakukan budidaya jamur tiram (Fritz, dkk., 2017).

Menurut Badan Pusat Statistik tahun 2017 tingkat konsumsi jamur di Indonesia mencapai 47.753 ton sedangkan produksinya hanya 37.020 ton. Setiap tahun permintaan jamur tiram meningkat $10 \%$ baik untuk kebutuhan hotel, restoran, vegetarian dan lain sebagainya (Kalsum, dkk.. 2011). Produksi Jamur tiram masih rendah karena permintaan konsumen cukup tinggi (Karisman, 2015). Untuk itu kita harus meningkatkan lagi produksi jamur tiram putih untuk memenuhi kebutuhan masyarakat. Melalui kegiatan pengabdian kepada masyarakat ini dengan budidaya rumah jamur dan olahannya dapat lebih meningkatkan kesejahteraan masyarakat dan menambah income masyarakat setempat.

Metode yang digunakan dalam kegiatan ini sesuai dengan diskusi tim abdi masyarakat dengan Kepala Desa adalah: Pemberian Materi tentang budidaya jamur 
tiram dan olahannya; Diskusi tentang berbagai masalah dan solusinya; Manajemen Usaha dan Pemasaran Produk; Simulasi dan evaluasi. Materi yang diberikan terdiri dari (1) manfaat jamur tiram bagi masyarakat; (2) budi daya jamur tiram; dan (3) pengolahan jamur tiram.

\section{TINJAUAN PUSTAKA}

Pemberdayaan masyarakat atau pengabdian merupakan suatu kegigihan dan kemampuan masyarakat dalam mensejahterakan keluarga mereka. Pengabdian yang dilakukan yaitu Budidaya dan pengolahan produk jamur tiram. Prospek budidaya jamur tiram sangat menjanjikan jika kualitas dan kuantitas produk sesuai dengan persyaratan. Usaha jamur tiram tidak menimbulkan kerusakan pada lingkungan dan dapat mengurangi limbah. Pembuatan media tanam jamur tiram terdiri dari serbuk kayu gergaji yang merupakan limbah dari pengrajin kayu dan bekatul sebagai nutrisi serta kapur atau dolomit untuk mengatur pH media (Suharnowo, dkk., 2012).

Media tanam jamur tiram putih yaitu serbuk gergaji, bekatul dan kapur. Serbuk gergaji memiliki kandungan lignin dan nutrisi yang sangat dibutuhkan untuk pertumbuhan jamur tiram. Pemilihan serbuk kayu dimaksudkan agar nutrisi yang terkandung di dalamnya dapat digunakan oleh jamur, untuk pertumbuhan jamur tiram menjadi lebih baik (Asegab, 2011). Begitupun dengan dedak yang dapat menjadi alternatif media tumbuh dari jamur karena mengandung protein, selulosa, serat, nitrogen, lemak, dan $\mathrm{P}_{2} \mathrm{O}_{5}$ untuk nutrisi bagi pertumbuhan jamur tiram (Ganders, 1986).

Kapur atau dolomit berfungsi untuk mengontrol $\mathrm{pH}$ media tanam, untuk pertumbuhan jamur yang optimal. Media dengan $\mathrm{pH}$ yang sesuai dengan pertumbuhan jamur dapat mempengaruhi ketersediaan beberapa unsur yang diperlukan untuk pertumbuhan jamur (Suriawiria, 2000). Salah satu cara untuk memanfaatkan serbuk gergaji adalah dengan menjadikannya sebagai bahan utama jamur tiram putih karena 
tingginya limbah gergaji yang disebabkan oleh produksi kayu perabotan rumah tangga

di Indonesia yang terbuang dan tidak dimanfaatkan lagi. Untuk mengurangi limbah serbuk gergaji salah satu caranya adalah dengan memanfaatkan sebagai bahan utama dari media tanam jamur tiram putih yang bernilai ekonomis dan ramah lingkungan.

\section{METODE KEGIATAN}

Metode yang digunakan dalam kegiatan ini adalah: Penyampaian Materi tentang budidaya jamur tiram dan olahannya; Diskusi tentang berbagai masalah dan solusinya; Manajemen Usaha dan Pemasaran Produk; Simulasi dan evaluasi.

Seluruh kegiatan melibatkan mahasiswa Kuliah Kerja Nyata Universitas Riau, masyarakat setempat yang dihadiri oleh ibu-ibu PKK, Karang Taruna, Kepala Desa, dan perwakilan aparat Desa Desa Seko Lubuk Tigo. Kegiatan pertama yang dilakukan adalah penyuluhan dengan penyampaian materi budidaya jamur tiram dan pengolahan produk jamur tiram menjadi berbagai macam penganan. Pada kegiatan ini juga dilakukan diskusi berupa Tanya jawab tentang berbagai masalah budidaya jamur tiram dan memberikan solusinya. Kegiatan selanjutnya adalah pelatihan membuat olahan produk jamur tiram. Olahan jamur tiram berupa pembuatan nugget jamur, jamur krispy, rendang jamur dan abon jamur tiram. Pada kegiatan ini juga disampaikan tentang manajemen usaha dan pemasaran produk sehingga nantinya dapat memasarkan produk jamur tiramnya. Kegiatan yang terakhir adalah praktek pembuatan jamur tiram dan olahan produk jamur tiram.

\section{HASIL DAN PEMBAHASAN}

Desa Seko Lubuk Tigo yang letaknya cukup strategis di jalur lintas Timur Sumatera, serta belum adanya budidaya jamur tiram di Desa tersebut dan tersedianya bahan baku untuk pembuatan jamur tiram maka berdasarkan sumber daya alamnya tersedia di Desa 
baik limbah dari serbuk.gergaji yang cukup melimpah untuk media tanam jamur tiram sehingga tidak perlu membeli lagi. Sumber tenaga kerjamya yang cukup.semangat utk menjadi petani jamur dan yang tak kalah penting di desa tersebut belum ada yang menanam jamur tiram., maka solusi yang tepat untuk masyarakat Desa Seko Lubuk Tigo adalah pengembangan (pemberdayaan) jamur. Pengabdian ini telah berhasil membudidayakan jamur tiram dan dapat dimanfaatkan sebagai sumber gizi bagi masyarakat setempat. Dan juga telah dilakukan pelatihan tentang produk olahan jamur tiram. Pelaksanaan kegiatan dengan melibatkan mahasiswa Kuliah Kerja Nyata Universitas Riau sebagai fasilitator pada bulan Juni-Oktober 2019.

Budidaya jamur merupakan teknologi tepat guna yang tidak membutuhkan biaya besar dan tidak begitu rumit dalam pelaksanaannya sehingga bisa dikerjakan oleh masyarakat setempat. Budidaya jamur tiram membutuhkan waktu panen hanya 1.5 bulan, tidak butuh pupuk, tidak mengenal musim, bisa dilakukan dalam skala home industry dan oleh siapa saja. Sisa dari produk jamur tiram dapat dimanfaatkan sebagai kompos dan makanan ikan, selain itu juga sudah bisa digunakan sebagai media untuk perkembang biakan cacing.

Kandungan nutrisi jamur tiram dibandingkan dengan jenis jamur kayu lainnya lebih tinggi. Kandungan asam amino 18 jenis diantaranya isoleusin, lysin, methionin, eystein, penylalanin, tyrosin, treonin, tryptopan, valin, arginin, histidin, alanin, asam aspartat, asam glutamat, glysin, prolin, dan serin. Jamur Tiram mengandung protein nabati yang cukup tinggi, lemak, dan unsur lainnya seperti vitamin, besi, fosfor dan lain sebagainyadan tidak mengandung kolesterol (Tabel 1). 
Tabel 1. Komposisi dan Kandungan Nutrisi Jamur Tiram per 100 gram

\begin{tabular}{cc}
\hline Zat Gizi & Kandungan \\
\hline Kalori & $367 \mathrm{kal}$. \\
Protein & $10,5-30,4 \%$ \\
Karbohidrat & $56,6 \%$ \\
Lemak & $1,7-2,2 \%$ \\
Thiamin & $0,20 \mathrm{mg}$ \\
Riboflavin & $4,7-4,9 \mathrm{mg}$ \\
Niacin & $77,2 \mathrm{mg}$ \\
Ca (Kalsium) & $314,0 \mathrm{mg}$ \\
K (Kalium) & $3.793,0 \mathrm{mg}$ \\
P (Posfor) & $717,0 \mathrm{mg}$ \\
Na (Natrium) & $837,0 \mathrm{mg}$ \\
Fe (Besi) & $3,4-18,2 \mathrm{mg}$ \\
\hline
\end{tabular}

Sumber: Djarijah dan Abbas, 2001

Jamur tiram memiliki sifat menetralkan racun dan zat-zat radioaktif dalam tanah.

Khasiat jamur tiram untuk kesehatan adalah mencegah penyakit diabetes melitus, menghentikan pendarahan dan menurunkan kolesterol darah mempercepat pengeringan luka pada permukaan tubuh, menambah vialitas dan daya tahan tubuh, serta mencegah penyakit tumor atau kanker, kelenjar gondok, influenza, sekaligus memperlancar buang air besar.

\subsection{Pelatihan Budidaya Jamur Tiram}

Praktek pelatihan budidaya jamur tiram terbagi menjadi beberapa tahapan, yaitu penyiapan serbuk gergaji, pencampuran media, pengomposan, pembuatan baglog, sterilisasi, inokulasi, dan inkubasi dan pemeliharaan.

\subsubsection{Penyiapan Serbuk Gergaji}

Serbuk gergaji sebanyak $75 \%$ dilakukan pengayaan terlebih dahulu sebelum dicampur dengan bahan-bahan seperti bekatul dan kapur. Pengayakan dilakukan, pada prinsipnya adalah untuk menyeragamkan ukuran serbuk gegaji. Tujuannya supaya pencampuran serbuk kayu dengan bahan-bahan yang lainnya dapat merata, sehinnga nantinya pertumbuhan miselia jamur dapat tumbuh dengan merata (Gambar 1). 


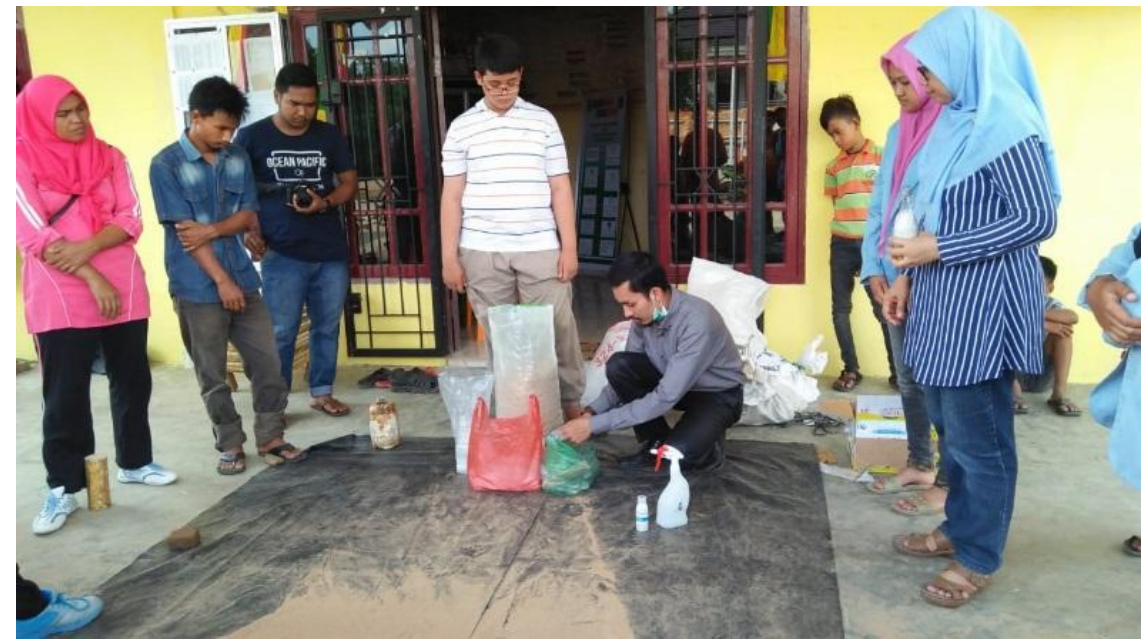

Sumber: Data primer diolah (2019)

Gambar 1. Persiapan serbuk gergaji pembuatan baglog

\subsubsection{Pencampuran Media}

Serbuk gergaji yang telah ditakar dicampur dengan campuran bahan-bahan lain seperti kapur, dan bekatul di tempat yang terpisah. Komposisi bekatul dan kapur pada masingmasing baglog sama yaitu $20 \%$ dan 5\%. Campuran media yang sudah merata selanjutnya dicampur dengan air sampai diperoleh kadar air media campuran $60 \%$ dengan ciri-ciri hingga kenampakan campurannya jika media tanam digenggam, kemudian genggaman tangan dibuka maka media campuran tidak hancur, tetapi juga mudah dihancurkan dengan tangan (Gambar 2)

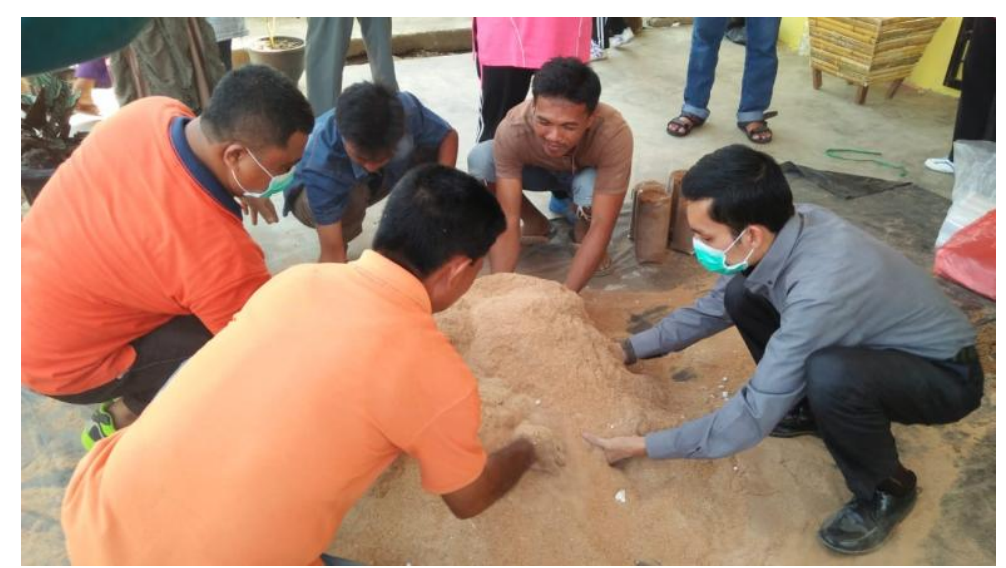

Sumber: Data primer diolah (2019)

Gambar 2. Pencampuran Media untuk pembuatan baglog 


\subsubsection{Pengomposan}

Setelah media tanam jamur selesai, kemudian ditutup menggunakan terpal. Pengomposan pada media tersebut dilakukan selama 5 (lima) hari supaya campuran komposisi media tercampur dengan merata. Terjadinya fermentasi dalam media ditunjukkan dengan adanya perubahan struktur yang menjadi lebih halus, warna yang menjadi lebih gelap dan memiliki aroma yang khas pada kayu.

\subsubsection{Pembuatan Baglog}

Setelah proses fermentasi, kemudian dimasukkan ke dalam kantong plastik polipropilen (PP) ukuran 1500 g dengan berat total media tanam yaitu 1000 g. Selanjutnya media tanam di dalam kantong plastik (baglog) tersebut dipadatkan dengan cara dipukulkan ke tanah agar media tanam padat dan tidak mudah hancur.

\subsubsection{Sterilisasi}

Sterilisasi media dengan menggunakan autoclave pada suhu $121^{0} \mathrm{C}$ selama 45 menit. Media yang sudah disterilisasikan kemudian didinginkan selama 8-12 jam. Pendinginan media tanam dilakukan karena pada prinsipnya pendinginan dilakukan agar pada saat media tanam diinokulasi, bibit jamur tidak akan mati (Gambar 3).

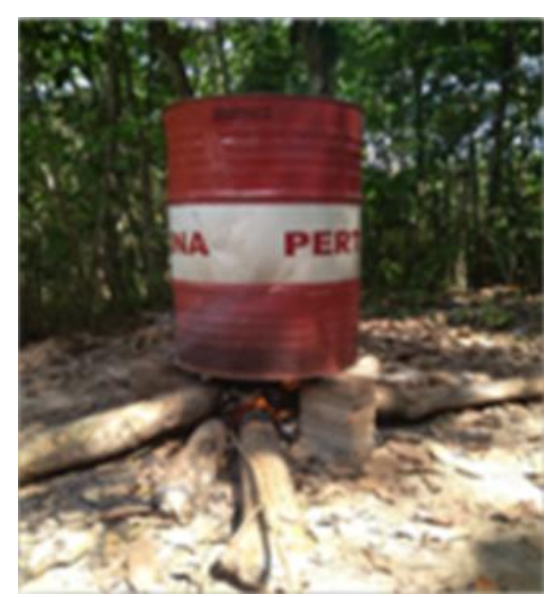

Sumber: Data primer diolah (2019)

Gambar 3. Sterilisasi baglog dengan sistem autoclave 


\subsubsection{Inokulasi}

Inokulasi dilakukan di ruang khusus yang sudah disterilisasi dengan menyemprotkan alkohol $70 \%$. Cara yang dilakukan dengan membuka penutup baglog kemudian bagian ujung dari baglog didekatkan pada bunsen, bibit jamur dimasukkan lewat cincin paralon bagian tengah dalam media. Inokulasi ini dilakukan satu per satu baglog.

\subsubsection{Inkubasi dan Pemeliharaan}

Inkubasi dilakukan dengan cara menyimpan pada rumah jamur dengan kondisi tertentu yang bertujuan supaya miselium jamur tumbuh dengan baik. Semua baglog ditempatkan di rak kayu dengan posisi horizontal dan dibiarkan sampai miselium jamur tiram putih tumbuh memenuhi seluruh baglog.

Kondisi ruangan inkubasi diatur dengan suhu $27-30^{\circ} \mathrm{C}$ dengan kelembaban $60-$ 70\%. Suhu dan kelembaban dalam ruangan dapat diatur dengan pengaturan sirkulasi udara dan penyiraman pada lantai kumbung apabila diperlukan. Kelembaban dan suhu diukur menggunakan termometer ruangan dan higrometer. Inkubasi diakhiri setelah 5-6 minggu yang ditandai dengan adanya miselium yang tampak putih merata menyelimuti seluruh permukaan media tanam (Gambar 4).

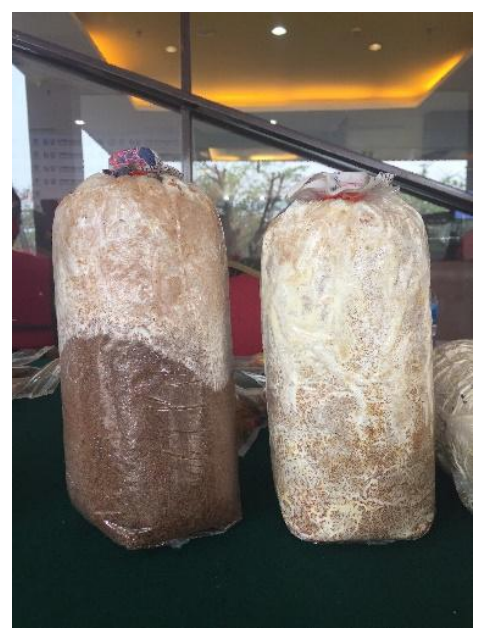

Sumber: Data primer diolah (2019)

Gambar 4. Baglog yang terdapat miselium pada tahap inkubasi 


\subsection{Pelatihan Pengolahan Produk Jamur Tiram}

Pelatihan tentang produk olahan jamur tiram dilakukan dengan ibu ibu PKK dan masyarakat setempat. Angket di sebarkan sebelum kegiatan dimulai, untuk mengetahui sejauh apa pengetahuan masyarakat tentang olahan jamur tiram. Ternyata dari hasil data angket yang telah dianalisis, sebanyak $77 \%$ telah mengetahui bahwa jamur tiram dapat diolah menjadi berbagai macam produk olahan. Tapi belum mengetahu bagaimana cara pengolahannya. Hal ini dapat dilihat dari angket memerlukan informasi tentang olahan produk jamur tiram sebesar $93 \%$ (Tabel 2)

\section{Tabel 2. Kuesioner Pemaanfaatan Produksi Rumah Jamur}

\begin{tabular}{clc}
\hline No & \multicolumn{1}{c}{ Pernyataan } & \multicolumn{1}{c}{ Persentase } \\
\hline 1 & $\begin{array}{l}\text { Daerah tempat tinggal saya memiliki permasalahan } \\
\text { dalam produksi rumah jamur }\end{array}$ & $73 \%$ \\
2 & $\begin{array}{l}\text { Salah satu penyebab permasalahan karena masyarakat } \\
\text { kurang termotivasi }\end{array}$ & $83 \%$ \\
3 & $\begin{array}{l}\text { Kegiatan rumah jamur menurut saya tidak penting } \\
4\end{array}$ & $\begin{array}{l}\text { Salah satu cara meningkatkan perekonomian keluarga } \\
\text { melalui usaha rumah jamur }\end{array}$ \\
5 & $\begin{array}{l}\text { Saya telah membaca dan mempelajari buku/berita terkait } \\
\text { pengelolaan rumah jamur }\end{array}$ & $51 \%$ \\
6 & $\begin{array}{l}\text { Saya telah mengetahui bahwa jamur tiram dapat diolah } \\
\text { menjadi berbagai macam produk olahan }\end{array}$ & $77 \%$ \\
7 & $\begin{array}{l}\text { Saya memerlukan informasi tentang olahan produk } \\
\text { jamur tiram }\end{array}$ & $93 \%$ \\
\hline Sumber: Data Primer Diolah (2019)
\end{tabular}

Kegitan pengabdian desa binaan di Desa Seko Lubuk Tigo diterbitkan di surat kabar harian 'Tribun' edisi 05 November 2019 (Gambar 5). Masyarakat Desa Seko Lukbuk Tigo sangat antusias dalam pelaksanaan kegiatan ini. Kendala yang di hadapi dalam kegiatan ini adalah untuk keberlajutan rumah jamur ini harus benar benar di kelola dengan baik dan selalu memberikan motivasi dan semangat kepada masyarakatnya. 


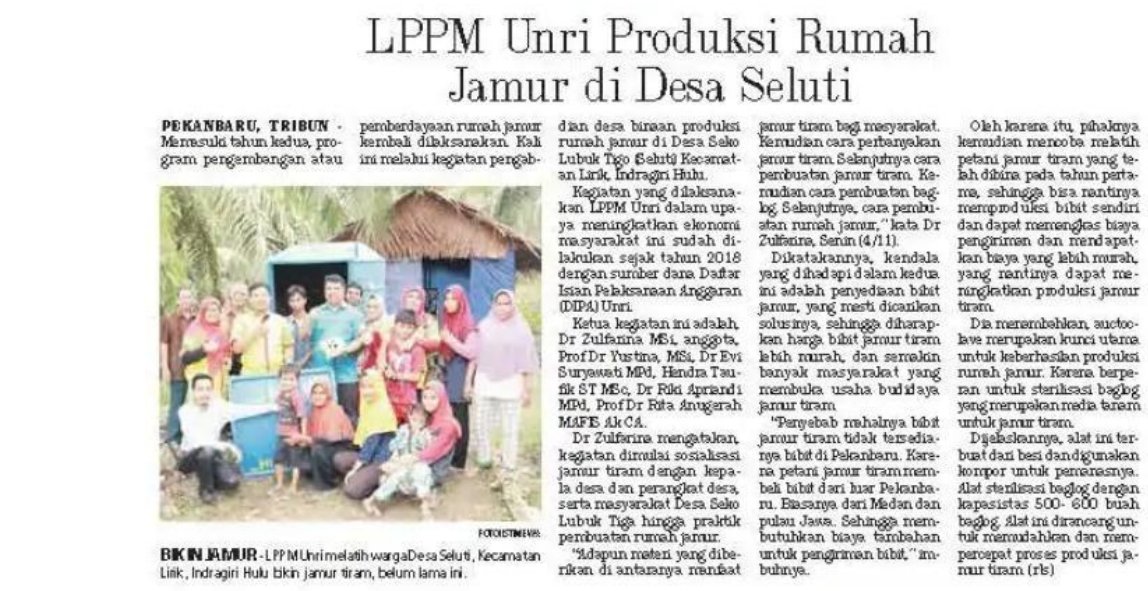

Sumber: Data primer diolah (2019)

Gambar 5. Berita Desa Binaan Produksi Rumah Jamur di SELUTI Kecamatan Lirik di

Koran Tribun edisi 5 November 2019

Usaha Jamur Tiram pada saat ini prospeknya cukup bagus dilihat dari permintaan pasar yang terus meningkat. Baik itu berupa jamur segar maupun produk olahannya. Dilihat dari kandungan zat gizi dari jamur ini dapat dimanfaatkan untuk kesehatan. Dari pelatihan budidaya jamur tiram yang telah dilakukan masyarakat secara cepat dapat menerapkan langsung di lapangan artinya budidaya jamur tiram sangat mudah untuk dilakukan.

\section{KESIMPULAN}

Masyarakat desa Seko Lubuk Tigo Kecamatan Lirik memiliki respon yang sangat positif terhadap kegiatan pengabdian Budidaya dan olahan jamur tiram. Hal ini dapat dilihat dari semua kegiatan yang telah dilakukan masyarakatnya sangat tertarik dan berperan aktif dalam kegiatan budidaya dan olahan jamur tiram.

Masyarakat Seko Lubuk Tigo Kecamatan Lirik Kabupaten Indragiri Hulu yang selama ini belem mengetahui cara budidaya dan olahan jamur tiram dengan adanya pengabdian desa binaan dari Universitas Riau telah berhasil mentransfer teknologinya sehingga mansyarakat mampu melakukan budidaya jamur tiram. 


\section{UCAPAN TERIMA KASIH}

Terima kasih diucapkan kepada Kementerian Riset dan Pendidikan Tinggi yang telah membiayai kegiatan pengabdian ini melalui dana DIPA UNRI sesuai dengan surat perjanjian pelaksanaan kegiataan No. 1119/ UN.19.5.1.3/ PT.01.03/2019. Terimakasih juga kami ucapkan kepada LPPM Universitas Riau yang telah mendukung kegiatan pengabdian ini serta semua pihak yang telah banyak membantu sehingga selesainya kegiatan ini.

\section{DAFTAR PUSTAKA}

Alexopolous, C. J. (1962). Introductory Mycologys. New York: John Willey and Son's. Asegab Muad. (2011). Bisnis Pembibitan Jamur Tiram, Jamur Merang dan Jamur Kuping. Jakarta: PT Agromedia Pustaka.

Badan Pusat Statistik. (2017). Statistik Tanaman Sayuran dan Buah-buahan Semusim Indonesia. Badan Pusat Statistik. Jakarta.

Cahyana, Y.A., M. Muchrodji, dan Bakrun. 1999 Jamur Tiram (Pembibitan, Pembudidayaan, Analisis Usaha). Jakarta: Penebar Swadaya.

Djarijah, N.M. dan Abbas, S.D. 2001. Budidaya Jamur Tiram (Pembibitan Pemeliharaan dan Pengendalian Hama-Penyakit). Yogyakarta: Kanisius.

Fritz Tanza Sitompul, Elza Zuhry, dan Armaini. (2017). Pengaruh Berbagai Media Tumbuh dan Penambahan Gula (Sukrosa) terhadap Pertumbuhan Jamur Tiram Puth (Pleurotus ostreatus). JOM Faperta, 4(2): 1-15. Pekanbaru: Fakultas Pertanian Universitas Riau.

Ganders, R. (1986). Bercocok Tanam Jamur Merang. Bandung: CV Pioner Jaya. 
Ibrahim, H. (2012). Laporan Akuntabilitas Kinerja Instansi Pemerintah Direktorat Jendral Hortikultura TA 2012. [Laporan]. Jakarta: Direktorat Jendral Hortikultura, Kementan.

Islami, A., Adi Setyo Purnomo, dan Sukesi. (2013). Pengaruh Komposisi Ampas Tebu dan Kayu Sengon sebagai Media Pertumbuhan terhadap Nutrisi Jamur Tiram (Pleurotus ostreatus). Jurnal Sains dan Seni Pomits, 2(1): 2337-3520.

Kalsum, U., Siti Fatimah, dan Catur Wasonowati. (2011). Efektivitas Pemberian Air Leri terhadap Pertumbuhan dan Hasil Jamur Tiram Putih (Pleurotus ostreatus). AGROVIGOR, 4(2): 86-92.

Karisman, W. (2015). Pengaruh Perbandingan Limbah Serbuk Kayu dan Blotong terhadap Produksi Jamur Tiram Putih (Pleurotus ostratus). Prosiding Seminar Nasional Pendidikan Biologi. UMM Malang.

Monografi Desa Seluti. (2018). Desa Seko Lubuk Tigo Kecamatan Lirik Kabupaten Indragiri Hulu. Diambil dari http://sekolubuktigo.sideka.id/

Suharnowo, L. S. Budipramana, dan Isnawati. (2012). Pertumbuhan Miselium dan Produksi Tubuh Buah Jamur Tiram Putih (Pleurotus ostreatus) dengan Memanfaatkan Kulit Ari Biji Kedelai Sebagai Campuran pada Media Tanam. LenteraBio, 4(1): 125-130.

Suriawiria. (2002). Budidaya Jamur Tiram. Yogyakarta: Kanisius

Suriawiria Unus. (2000). Sukses Beragrobisnis Jamur Kayu: Shitake, Kuping, Tiram. Jakarta: Penebar Swadaya.

Windyastuti, PW. (2000). Analisis Pendapatan dan Efisiensi Penggunaan Faktor-faktor Produksi Usahatani Jamur Tiram Putih (Studi Kasus di Desa Tugu Utara, Kecamatan Cisarua, Kabupaten Bogor, Propinsi Jawa Barat). Bogor: IPB, Fakultas Pertanian. 